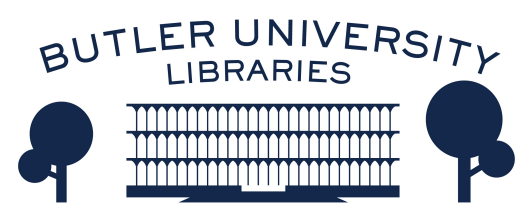

Journal of Hindu-Christian Studies

Volume 2

Article 9

January 1989

\title{
Book Review: "Mission Today -- Reflection from an Ignatian Perspective"
}

Vincent Sekhar

Follow this and additional works at: https://digitalcommons.butler.edu/jhcs

Part of the Religion Commons

\section{Recommended Citation}

Sekhar, Vincent (1989) "Book Review: "Mission Today -- Reflection from an Ignatian Perspective"," Journal of Hindu-Christian Studies: Vol. 2, Article 9.

Available at: https://doi.org/10.7825/2164-6279.1018

The Journal of Hindu-Christian Studies is a publication of the Society for Hindu-Christian Studies. The digital version is made available by Digital Commons @ Butler University. For questions about the Journal or the Society, please contact cbauman@butler.edu. For more information about Digital Commons @ Butler University, please contact digitalscholarship@butler.edu. 
the well-known Danish missiologist. There are eighteen contributions in this volume by different scholars. First, three articles highlight Johannes Aagaard as a missiologist. Four articles deal with Indological themes of classical Hinduism. There are two contributions taking us into the Islamic world-view. The rest of the book treats the missiological issues such as Church and World, St. Paul's mission to the Greeks, the role of the apologetic in Christian theology, inculturation and so on. The editors could have classified the articles better thereby indicating the different dimensions of the Dialogue in Action.

Lars Thunberg presents briefly Johannes Aagaard the missiologist surveying his contribution to the missiology of recent times. $\mathrm{He}$ underlines mainly Aagaard's understanding of the relationship between Church and mission giving a summary of JAA's Seven Thesis on Mission. Svend C. Boysen highlights the trademark of the work of JAA, which is made up of mission-dialogue in confrontation, personal commitment and practical application. Especially JAA wants to promote dialogue of reconciliation between those who lean towards an inclusivistic approach and those with an exclusivistic attitude "in order to fight the devastating sectarianism which constitutes a decisive threat to mission theology" ( $p$. 39).

Dialogue in Action is by and large the underlying thread that brings together all the contributions in this volume. But the understanding of dialogue and the theological perspective vary. The use of the term dialogue found in all the articles does not warrant a commonly agreed perspective in the book. Lissi Rasmussen argues forcefully for diapraxis; otherwise dialogue would be an academic exercise. Some are apprehensive about entering into dialogue with various religious movements since dialogue will water down the orthodoxy of one's religious tradition. One can perceive this trend in Friedrich $W$. Haack's contribution on Apologetic. In a similar vein but in anthropological framework Stephen Fuchs points out the dangers and limitations of inculturation, since that will not help very much perhaps to preach the Christian faith in some cultures like that of India and China. Sometimes dialogue could take the form of inculturation depending on the underlying motive of those engaged in it.

The contribution on Indological themes has to be taken in a broader sense of dialogue in action. In an inquiry into the Upanisadic prayer Gispert-Sauch brings in his exegetical skill to highlight the meaning and significance of this prayer: asatoma sad gamaya. With copious footnotes he tries to establish the original context in which this hymn was used and provides a fund of information on ritual tradition with a scholarly precision. Moti Lal Pandit analyses Patanjali's yoga text in the context of its goal - final freedom. For the beginners he provides a clear expose of the yoga in its philosophical context with reference to its original sources. J.V. Perreira traces the factors leading to the religio-nationalist movements in India and calls for a dialogue and ecumenism among constructive forces in India.

This felicitation volume is a fitting tribute to a scholar like Johannes Aagaard and a publication of this type draws the attention of the public to the man on focus and also becomes an occasion for further creative contribution from different scholars. A select bibliography of Johannes Aagaard at the end of the book speaks volumes for his dedication and scholarship.

Anand Amaladass

Satya Nilayam

Madras, India

Mission Today-Reflection from an Ignatian Perspective. Michael Amaladoss, S.J. Centrum Ignatianum Spiritualitatis, Rome, 1988, pp. 171.

Mission Today is a vital and a central concern to anyone who sees this universe as one community. It is not exclusive to those engaged in public service alone but to any ordinary human being who understands his surroundings and acts meaningfully.

In a society it is very difficult to adapt oneself to changing conditions. It requires a discerning spirit to reflect spiritually and theologically on the state of flux to maintain a smooth rhythm of life.

Dr. Michael Amaladoss, one of the Assistants and Counsellor to the Jesuit General, a noted theologian and Liturgist, describes this Mission constantly guided by the inspirations of St. Ignatius of Loyola. He employs a hermeneutical approach by rereading the texts of Ignatius like the spiritual Exercises, the Autobiography, the Diary and the Constitutions in the context of today.

The Book contains six chapters. The first describes the contemporary challenges and the next deals with the response to these challenges in the light of St. Ignatius. The rest of the chapters are divided each into two sections. The first describes the nature of the challenge and the second examines the Ignatian understanding relevant to that challenge. In other words, the author has followed a "Context-text" methodology to bring meaning to both the Texts and the Context.

The book opens with the contemporary challenges in Mission, particularly of evangelization in a multifarious religious and cultural context. The Mission of the Church in such a context is to advance human and civic culture. In this process Culture or Religion does not become a means but a reality in which the seed of the Grospel fructifies. In it justice and dialogue works are never compartmental but mutually embracing dimensions of Mission.

The author explicitly mentions three types of challenges in the present WorldContext, viz., the challenge to believe, the challenge to dialogue and the challenge to do justice. These, again, stem from a world of despair, conflicts and oppression.

First of all the Mission is to meet the challenge of secularizing, materialistic tendency promoted and safeguarded by Science and Technology, Industrialization and Urbanization. To free oneself from this clutch some prefer drugs and others go to the other extreme of becoming fundamentalists. But they do not prove an adequate response to the crisis. Here the Ignatian insight would be useful. He sees God in all things and in fact Science, etc. are God's gifts to humanity. One need not run away from or shun God's creation. The famous rule of "tantum-quantum" (so much-that much) inspires him to handle the situation.

Secondly the Mission is to meet the challenge of dialoguing with other faiths and ideologies. It is both a personal and an institutional encounter which reveals something new leading to newer forms of relationship. Authentic dialogue consists in a search in the context of the other. It should also preserve an autonomy of both which may be manifested in witnessing and proclaiming. In countries like India, where there are divergent religious forms, dialogue becomes more intriguing and complex. It requires a background knowledge of the religious and philosophical traditions of the other and an attitude of humble acceptance that one's own traditions and faith expressions are limited and conditioned in many ways.

While reflecting on the significance of dialogue Dr. Amaladoss points out that no religion can claim monopoly of God's action in this world. His argument is supported by the insights of Ignatius. The Ignatian use of mediators in and through whom God works is an important insight in the present context. God makes use of persons. His revelations are communicated to persons and are manifested in the forms of Scriptures, Sacraments, the 
Church-institution, etc. Hence the diverse forms of religion and culture are but different types of manifestations of God and consequently, a great respect for the mystery of God's action in each religion and culture is demanded. The Trinitarian experience of Ignatius is but an example of how God relates to the plurality of persons, freedoms and relationships.

Lastly the Mission is to meet the challenge of doing justice in the context of exploitation and oppression. The author outlines briefly the new awareness among those involved in the cause of the poor, taking into account the supportive economic and political structures in society.

While it is imperative to fight against economic inequality, etc. the writer points out the basic option of Ignatius for poverty in his contemplation on the "Two Standards" where he relates economics and spirituality by linking riches to honour and poverty to humiliations. This exercise is not merely a parable but a paradigm as well that shapes man's attitudes and actions. The application of the principle of "tantum-quantum" is pertinent here. Incidentally the Ignatian rules for Distribution of Alms with an attitude of detachment and the rules in the matter of food as a means of selfcontrol confirm his basic option. What Ignatius said about freeing oneself from detachment could be interpreted today as also freeing oneself from all sinful structures.

The author says that we need to approach liberation in a holistic manner. Economic inequality is but one of the many forms of injustice in the world, other forms being offences against human dignity, real equality and community, etc. The optimistic note is that already our ideas are changing from an individualistic towards a more holistic perspective.

In such a context Dr. Amaladoss pictures the Mission of the Church/ Religion as a prophetic Force, criticising what is evil, inspiring what is good and guiding towards the Kingdom. In the process it has to explore strategies, ideologies and political movements.

The book ends with a chapter on the relevance of the church today in the modern world. Here it may be useful to point out three things: the nature, the focus and the manner of involvement of the church. The church should be a dynamic movement with the principle of Incarnation basically operating in it. There is reason for saying this. The church wants to be ever new and at the same time work out ways and means for stability. In this process it faces a number of problems. In such a precarious situation Ignatian insights would be useful. The attitude of
Ignatius is seen in the Rules for conforming with the Church. It might seem onesided and narrow when taken out of context but when seen in the total perspective of the Spiritual Exercises, where one seeks the will of God throughout, it is a much needed help to see one's own special mission. The instructions given with regard to making a good election also helps him find the will of God and make the choice freely. For Ignatius there is no conflict between the Church's directives, God's call and the charism of the individual.

But still Dr. Amaladoss would stress that the Church must keep a delicate balance between unity and pluri-formism and the Church's directives must be inspired by the new and changing worldcontext. The Church's involvement should be directed towards the common good, going beyond its structural and ideological limitations.

Being a third world theologian Dr. Amaladoss is familiar with the Asian and, more particularly, the Indian scene with all its pluri-cultural and religious forms and the pressing problems like poverty, oppression and exploitation. Although the Mission concerns the whole world and calls for global activity, the book provides enough challenges to both Activists and Spiritualists.

Vincent Sekhar, S.J.

Madras, India

Wilhelm Halbfass, India and Europe. An Essay in Understanding. Albany, NY: State University of New York Press, 1988, pp. $x i+604$.

Halbfass' objective is to discuss the "philosophical dialogue" between India and Europe from the days of the antiquity up to the present era, thus excluding the most recent developments. One hopes that Halbfass is planning to write a supplementary volume dealing with the evolvements of the 20th century and their implications upon this dialogue. The present study is divided into three parts. The first one is devoted to Europe's image of India and its reception of Indian thought. The second part deals with India's response to the challenge posed by Europe's interest in India; and the third part contains "illustrations and reflections".

The bulk of the book is descriptive. From the early days of ancient Greek thinkers up to 19th century European philosophers, Halbfass describes the major traits of Europe's reception of Indian thought. In great detail and with scholarly thoroughness the prominent ideas of each thinker and era are described whereby the question, what constitutes "true philosophy" is at the centre of Europe's rejection of Indian thought. Indian thought seems to the Europeans burdened with legends, myths, and superstitions. Therefore Oriental thought in general, but Indian thought in particular, can only be considered to be a precursor of "true" philosophizing as it was developed by the Greeks, as Hegel has argued. This ethnocentric depreciation of Indian thought accounts, according to Halbfass, for the fact that very few, if any, philosophy departments incorporated a treatment of Indian thought in their academic curricula.

By contrast, India showed little interest in reacting to the economic, military, and philosophical intrusion of its territory by occidental powers. If we were to rely on Indian sources solely, we hardly could guess that Alexander the Great's campaign had ever happened. Halbfass sees India's drive for reflecting upon occidental philosophy rooted in the global "westernization" which has spread a largely uniform thinking across the world. Thus it becomes questionable whether one can call such an imbalanced communication a dialogue which by definition presupposes two equal partners engaging in an exchange of mutually relevant and interesting ideas. It seems that the interaction between the two civilizations was stifled for both being enmeshed in ethnocentric and patriarchal thinking, although of opposite nature: India closing itself off in xenophobic traditionalism, and Europe subjecting other continents to its own way of thinking which it considers to be of global relevance (with a few exceptions such as German romanticism). While the Indian tradition has a paramount tendency to include alien systems of thought into the lower levels of its own, Europe discredited them on accounts that they did not meet the criteria defined by its own systems. Inclusivism and exclusivism are diametrically juxtaposed and constitute the parameters for the economy of this communication.

In his conclusive remarks, unassumingly placed in the appendix, Halbfass again points at Hegel as the occidental thinker who articulated the superiority of Europe's "philosophy" over Indian "thought", a viewpoint reiterated, with some modifications, by Husserl. He ends the discussion by referring to Heidegger who saw in the global "Europeanization" the phenomenological context within which future communication between Occident and Orient has to happen. Although reference is made to transcending "Orient" and "Occident," alter- 